\title{
KEEPING THE DOOR OPEN: A MIDDLE GROUND ON THE QUESTION OF AFFIRMATIVE DUTY IN THE PUBLIC SCHOOLS
}

\author{
MichaEL GiLbeRT $\dagger$
}

\section{INTRODUCTION}

This Comment deals with ugly and destructive instances of physical abuse and sexual molestation of children that occur in a setting that is supposed to be a sanctuary of safety and nurturancethe public school. Although the victims of these abuses have legal claims against the perpetrators of these destructive activities-be they teachers, school employees, or fellow students-they also have claims against school officials ${ }^{1}$ and school districts, under whose watch these incidents occur. These latter claims are the subject of this Comment. Many such claims are brought under state tort law, ${ }^{2}$ but this Comment examines liability for "constitutional torts"federal statutory-based liability under Section 1983 of the Civil Rights Act of $1871 .^{3}$

† B.A. 1991, Tufts University; J.D. Candidate 1994, University of Pennsylvania. I would like to thank Erica and Evan Dody for selflessly allowing me to write the first draft of this Comment in their playroom. I also thank Professors Ralph Smith and Barbara Bennett Woodhouse for their advice, and Tony Klapper for his keen editorial insight. I am grateful to Susan Sciarratta for her quiet encouragement, and I dedicate this Comment, with love and respect, to my parents.

${ }^{1}$ As used in this Comment, this includes principals, school board members, and superintendents.

${ }^{2}$ See Smith v. School Admin. Dist. No. 58, 582 A.2d 247 (Me. 1990) (involving an action brought by a student and her parents against a school district for injuries sustained by the student on a school playground); Gardner v. City of Biddeford, 565 A.2d 329 (Me. 1989) (involving a state tort law claim alleging unlawful sexual contact with student); Logan v. City of New York, 543 N.Y.S.2d 661 (App. Div. 1989) (alleging school's negligent supervision resulted in rape of student by another student); Medlin v. Bass, 386 S.E.2d 80 (N.C. Ct. App. 1989) (holding that a school superintendent was negligent in hiring a principal with a history of sexual assault).

3 Section 1983 in pertinent part provides:

Every person who, under color of any statute, ordinance, regulation, custom, or usage . . . subjects, or causes to be subjected, any citizen of the United States or other person within the jurisdiction thereof to the deprivation of any rights, privileges, or immunities secured by the Constitution and laws, shall be liable to the party injured in an action at law, suit in equity, or other proper proceeding for redress.

42 U.S.C. § 1983 (1988).

As a practical matter, there are a number of reasons why Section 1983 claims are brought instead of, or in addition to, state tort law claims. First, a Section 1983 
Although Section 1983 liability can be established under two theories, ${ }^{4}$ this Comment concentrates solely on claims asserting that public school officials and districts have an affirmative duty to protect the student/victim from harm. Once the plaintiff establishes that the school officials and districts have such a duty, the plaintiff must then prove that the school defendants breached that

action will guarantee access to federal court, which the plaintiff may prefer for strategic reasons. See 28 U.S.C. \$ 1331 (1988) (providing federal court jurisdiction in cases where a federal statutory question is presented in a well-pleaded complaint). Second, under the Civil Rights Attorney's Fees Awards Act of 1976, 42 U.S.C. § 1988 (1988), victorious Section 1983 plaintiffs are entitled, at the discretion of the court, to have attorneys' fees and costs included in their award. Third, state law immunities may bar certain actions that are not precluded under federal law. See, e.g., Flores v. Edinburg Consol. Indep. Sch. Dist., 554 F. Supp. 974, 978 (S.D. Tex. 1983) (noting that while state immunity barred state law relief, plaintiff could bring a Section 1983 action). Finally, some states, like Wisconsin, statutorily cap damage awards in tort cases against subdivisions of the state, whereas Section 1983 claims are not capped. See WIS. STAT. ANN. \$ 893.80 (3) (West 1983) ( $\$ 50,000$ limit). See generally William D. Valente, Liability for Teacher's Sexual Misconduct with Students-Closing and Opening Vistas, 74 Educ. L. Rep. (West) 1021, 1022 n.4 (1992) (listing advantages of Section 1983 actions as opposed to state law claims); Steven F. Huefner, Note, Affirmative Duties in the Public Schools After DeShaney, 90 Colum. L. REV. 1940, 1961 (1990) (discussing the additional protection Section 1983 provides as compared to state tort remedies).

While a complete description of who can be named as a defendant in a Section 1983 suit is beyond the scope of this Comment, a brief explanation may be helpful. In Monroe v. Pape, 365 U.S. 167 (1961), the Supreme Court held that local governments, including school boards, were not subject to suit under Section 1983. A 1978 opinion, Monell v. Department of Social Servs., 436 U.S. 658 (1978), reversed this holding and decided that "local governments" do count as "persons" under the statute. Id. at 690 . Additionally, the Monell court held that local government officials sued in their official capacity are "persons" and are subject to Section 1983 actions in the same manner as local municipalities. Id. at 700.

The Eleventh Amendment bars suits in federal court against states. See U.S. CONST. amend. XI (" $[\mathrm{T}]$ he Judicial Power of the United States shall not be construed to extend to any suit in law or equity, commenced or prosecuted against one of the United States . . . . ). Most school boards or school districts, however, are considered local governmental bodies, not arms of the state and thus can be sued in federal court. See Mt. Healthy City Bd. of Educ. v. Doyle, 429 U.S. 274 (1977). In some states, however, a suit directly against a school board will be barred by the Eleventh Amendment. For example, the Ninth Circuit in Belanger v. Madera Unified Sch. Dist., 963 F.2d 248 (9th Cir. 1992), stated that "California has selected a different path from that of most states. California has vested control of school funding in the state rather than local governments." Id. at 254. A determinative factor in the decision was the fact that school boards in California, unlike most school boards, do not derive their funding mainly through local property taxes. See id. For a complete discussion of Section 1983 actions, see generally SHELDON H. NAHMOD, CIVIL RIGHTS AND CIVIL LiberTiEs LITIGATION, THE LAW OF SECTION 1983 (3d ed. 1991).

${ }^{4}$ See infra text accompanying notes 14-18 (discussing the custom/policy theory of liability as well as the affirmative duty theory). 
duty by acting with "deliberate indifference" toward the injurious behavior. ${ }^{5}$ This is a higher standard than ordinary negligence. ${ }^{6}$

Part I of this Comment describes the general notion of liability for inaction and the circumstances in which courts will impose affirmative duties on the state. Part I then discusses DeShaney $v$. Winnebago County Department of Social Services ${ }^{7}$-the Supreme Court's most important pronouncement on this point-and the ambiguity left in its wake. While DeShaney itself deals with the question of when a social service agency incurs an affirmative duty, the doctrine announced by the Court in that case has been used to analyze whether courts should impose such a duty in the public school setting.

Part II examines how the ambiguity in DeShaney has led to conflicting lower court opinions on whether public school officials and districts have an affirmative duty to protect students from harm. Two recent decisions on this point reveal a "split in the circuits" on this issue. $^{8}$

5 The "deliberate indifference" standard derives from Eighth Amendment prisoner cases. See, e.g., Estelle v. Gamble, 429 U.S. 97, 104-06 (1976) (holding that "deliberate indifference" to a prisoner's serious medical needs must be proven in a Section 1983 claim). While the issue of what constitutes "deliberate indifference" is not the focus of this Comment, the Seventh Circuit's explanation of the term may be helpful:

[Deliberate indifference may be] evidenced by either actual intent or reckless disregard. Although the term "actual intent" is self-explanatory, reckless disregard is not. A defendant acts recklessly when he disregards a substantial risk of danger that either is known to him or would be apparent to a reasonable person in his position. Recklessness is characterized by highly unreasonable conduct or a gross departure from ordinary care in a situation where a high degree of danger is apparent. The standard is an objective one. Although subjective unawareness of the risk is no defense, the risk must be foreseeable. Indeed, risk is defined as a recognizable danger of injury. The risk also must be substantial.

Benson v. Cady, 761 F.2d 335, 339 (7th Cir. 1985) (citations omitted); see also City of Canton v. Harris, 489 U.S. 378, 388 (1989) (holding that "deliberate indifference" on the part of the state is necessary to establish a Section 1983 violation).

6 It is well established that the standard to demonstrate such a breach in a Section 1983 claim is one which is higher than ordinary negligence. See Daniels v. Williams, 474 U.S. 327, 333 (1986) (noting that mere negligence cannot "give rise to a due process 'deprivation'"). It should also be noted that some courts have cast the standard as one of "gross negligence." See Vinson v. Campbell County Fiscal Court, 820 F.2d 194, 199-200 (6th Cir. 1987).

7489 U.S. 189 (1989).

8 The two cases are the Third Circuit's decision in D.R. v. Middle Bucks Area Vocational Technical Sch., 972 F.2d 1364 (3d Cir. 1992) (en banc) (holding that the school district and school officials had no affirmative duty to protect its students from sexual abuse by classmates), cert. denied, 113 S. Ct. 1045 (1993) and the Fifth Circuit's opinion in Doe v. Taylor Indep. Sch. Dist., 975 F.2d 137 (5th Cir. 1992) (holding that 
Part III looks beyond the courts' categorical approach ${ }^{9}$ to determining when an affirmative duty should be imposed upon the state, and analyzes the underlying principle of vulnerability that drives the affirmative duty doctrine. Based on this principle, Part III suggests an appropriate standard for determining when, as a general matter, the state should incur an affirmative duty.

Finally, in Part IV, a middle ground on the question of affirmative duty in the public school context is suggested. The lower federal courts thus far have adopted an "all or nothing" approach to this issue. They have ruled either that school districts and officials never have an affirmative duty to protect students from harm, or alternatively, that the school defendants should always be held to such a duty. ${ }^{10}$ This Comment suggests, instead, that a court reluctant to expand the scope of affirmative duties should hold that public school officials and districts have an affirmative duty to protect students from abuse or molestation when it is perpetrated by teachers or school employees. In so ruling, a court would not necessarily be deciding that the school defendants have an affirmative duty in cases of abuse of students by other students.

As will be shown, this approach is consistent with the underlying principle of vulnerability discussed in Part III. Importantly, it leaves open the possibility of recovery for at least those students who are abused by teachers or school employees in jurisdictions that might otherwise completely foreclose liability for inaction in the public school setting.

\section{SECTION 1983 LIABILITY FOR INACTION AND THE DESHANEY DOCTRINE}

In order to establish a claim under Section 1983, the plaintiff must demonstrate that she was deprived, under color of state law,

superintendent and principal had an affirmative, constitutionally-based duty to protect student from sexual abuse by a teacher/coach in her high school), cert. denied, $113 \mathrm{~S}$. Ct. 1066, reh'g granted, 987 F.2d 231 (5th Cir. 1993).

${ }^{9}$ For a discussion of the courts' use of categorizing the factual content of cases (e.g., prisons, psychiatric hospitals, foster care) to determine whether an affirmative duty exists, see infra text accompanying notes $37-42$.

${ }^{10}$ By stating that the school defendants "should always be held to such a duty," it is not meant that whenever a student is injured at school, the school district or school officials will be liable. Even if the duty always exists, liability is incurred only when that duty has been breached by deliberately indifferent behavior on the part of the school defendants. 
of some existing federal right. ${ }^{11}$ In the cases considered herein, the underlying federal right is rooted in the Due Process Clause of the Fourteenth Amendment. ${ }^{12}$ Courts couch the right to be free from physical abuse or sexual molestation in terms of the constitutional right to bodily security. Generally, courts have accepted this as a sufficient and appropriate basis for these claims. ${ }^{13}$

Having established the underlying constitutional right, plaintiffs base their Section 1983 claims against school officials or districts on one of two theories. ${ }^{14}$ Under one approach, the plaintiff must demonstrate that the school defendants instituted a custom, practice, or policy "that condones or encourages" the mistreatment of students. ${ }^{15}$ The burden of proving that an official custom or

11 See supra note 3.

12 The Due Process Clause provides, in relevant part, that no State shall "deprive any person of life, liberty, or property, without due process of law." U.S. CONST. amend. XIV, § 1 .

13 The constitutional right to be free from physical or sexual abuse in school was recognized in Ingraham v. Wright, 430 U.S. 651, 673 (1977) ("Among the historic liberties so protected [by the Due Process Clause] was a right to be free from, and to obtain judicial relief for, unjustified intrusions on personal security."); see also White v. Rochford, 592 F.2d 381, 383 (7th Cir. 1979) (recognizing protection of the right to bodily security); William D. Valente, School District and Official Liability for Teacher Sexual Abuse of Students Under 42 U.S.C. \& 1983, 57 Educ. L. Rep. (West) 645, 646 n.7 (1990) (citing Ingraham and Stoneking v. Bradford Area Sch. Dist., 856 F.2d 599 (3d. Cir. 1988), as support for the proposition that there is a substantive constitutional right to be free from sexual abuse). For a detailed explanation of the contours of the underlying constitutional deprivation in cases of abuse and molestation of children in school, see Doe v. Taylor Indep. Sch. Dist., 975 F.2d 137, 141-48 (5th Cir. 1992), cert denied, 113 S. Ct. 1066, reh'g granted, 987 F.2d 231 (5th Cir. 1993).

${ }^{14}$ See Elliot v. New Miami Bd. of Educ., 799 F. Supp. 818, 820 (S.D. Ohio 1992) ("Courts ... have considered $\$ 1983$ liability for public schools which have failed to take action to protect a student based upon two theories: (1) constitutional duty analysis; and (2) policy, custom or practice analysis."). It should be noted that Section 1983 clearly does not impose vicarious liability on school districts and school officials. The Supreme Court, in Monell v. New York City Dep't of Social Servs., 436 U.S. 658 (1978), unambiguously declared that

the language of $\S 1983$, read against the background of the . . . legislative history, compels the conclusion that Congress did not intend municipalities to be held liable unless action pursuant to official municipal policy of some nature caused a constitutional tort. In particular, we conclude that a municipality cannot be held liable solely because it employs a tortfeasor-or, in other words, a municipality cannot be held liable under $\S 1983$ on a respondeat superior theory.

Id. at 691. Thus, in claims where the plaintiff has been abused or molested by a teacher or school employee, Section 1983 does not allow an agency-based theory of liability upon the school district.

15 See Elliot, 799 F. Supp. at 823; see also Monell, 436 U.S. at 690-91 (holding that Section 1983 suits against local governmental bodies are permissible if it can be 
policy is sufficiently related to the abuse or molestation is often difficult. ${ }^{16} \mathrm{~A}$ written policy indicating official failure to guard against mistreatment of students in the school rarely exists. Cases alleging that the policy or custom "ha[s] been manifested only by ... [a] pattern of action," as opposed to a written document, are even more difficult to prove. ${ }^{17}$

The concern of this Comment is not with the custom/policy approach, but with the affirmative duty theory. A plaintiff may establish Section 1983 liability by demonstrating that the defendants "had a duty to take affirmative steps to protect the plaintiff's liberty interests. ${ }^{18}$

It is well established that the state has no obligation to take affirmative action to protect any citizen from harm, just as it is generally accepted in the common law of torts that no citizen has a duty to "rescue," or come to the aid of, any other citizen. ${ }^{19}$ The

shown that the violation of a federal right was pursuant to a custom or policy).

${ }^{16}$ In the context of abuse or molestation in the schools, the officials' inadequate investigation is the policy or custom that the plaintiff alleges caused the violation of constitutional rights. See D.T. v. Independent Sch. Dist. No. 16, 894 F.2d 1176, 1188 (10th Cir. 1990) ("The School District could be held liable in this case under 1983 only if plaintiffs demonstrated a direct causal connection between the hiring, investigative, and supervising policy in question and the alleged constitutional deprivation." (citation omitted)).

The Supreme Court has taken a stringent view of the proof necessary to establish causation.

[Adopting] lesser standards of fault and causation would open municipalities to unprecedented liability under $\S 1983$. In virtually every instance where a person has had his or her constitutional rights violated by a city employee, a $\$ 1983$ plaintiff will be able to point to something the city "could have done" to prevent the unfortunate incident.

City of Canton v. Harris, 489 U.S. 378, 391-92 (1989); see also Barbara Kritchevsky, "Or Causes to be Subjected": The Role of Causation in Section 1983 Municipal Liability Analysis, 35 UCLA L. REv. 1187 (1988) (noting that the Supreme Court has not fully explained how policies or customs must be causally linked to a violation in order for liability to be imposed).

It may also be difficult to determine which public school superiors qualify as "policymakers" for the school or school district. The question of who is authorized to make policy or customs for a particular entity is often not a simple one. See City of St. Louis v. Praprotnik, 485 U.S. 112, 130 (1988) (holding that simply because decisions of certain supervisors are not subject to review does not mean these supervisors have policymaking authority).

${ }^{17}$ Valente, supra note 13 , at 647.

${ }^{18}$ Huefner, supra note 3, at 1941; see also DeShaney v. Winnebago County Dept. of Social Servs., 489 U.S. 189, 191 (1989).

${ }^{19}$ For some striking examples of the application of this doctrine, see Handiboe v. McCarthy, 151 S.E.2d 905, 907 (Ga. Ct. App. 1966) (holding that the defendant had no duty to rescue a child licensee drowning in a swimming pool); Osterlind v. Hill, 
only exception to the "no duty to rescue" rule arises when there is a "special relationship" between the victim and the would-be rescuer. In common-law tort, a special relationship arises in one of four circumstances: (1) where the defendant acts affirmatively to cause the peril faced by the plaintiff; (2) where the defendant undertakes to rescue the plaintiff; (3) where the plaintiff and defendant are in an appropriate "status" to one another (e.g., parent-child, landlord-tenant, etc.); and (4) where there is a contractual relationship between the parties. ${ }^{20}$

By contrast, under Section 1983, the determination of which situations place the state in a "special relationship" with a citizenand thus confer an affirmative duty to protect a citizen-is governed by constitutional interpretation and statutory construction. "[T]he Supreme Court's most forceful-and perhaps most controversialstatement yet about the limited circumstances in which the government has affirmative duties ... to protect its citizens"21 under Section 1983, is offered in DeShaney v. Winnebago County Department of Social Services. ${ }^{22}$

As Chief Justice Rehnquist, who authored the majority opinion, noted, "[ $t$ ] he facts of [the DeShaney] case are undeniably tragic." ${ }^{23}$ Melody and Randy DeShaney had a son, Joshua, in 1979. In 1980, the couple divorced, and Mr. DeShaney was awarded custody of Joshua. Mr. DeShaney remarried, and shortly thereafter divorced again. His second wife contacted the police in 1982 and complained that Mr. Deshaney "hit [Joshua], causing marks and [was] a prime case for child abuse." 24 In January of 1983 Joshua was admitted to a local hospital. He had multiple bruises and abrasions.

160 N.E. 301, 302 (Ohio 1928) (holding that defendant had no duty to rescue even where defendant rented a canoe to the intoxicated plaintiff); Yania v. Bigan, 155 A.2d 343, 346 ( $\mathrm{Pa}$. 1959) (holding that defendant had no duty to rescue even where defendant incited the plaintiff to jump into the water and then let him drown). This point is also made vividly clear in many first-year law classes through the oft-told (but fictitious) anecdote of the baby drowning in the lake as the Olympic swim team passes by, sees the child, and does nothing. Many students are shocked to learn that the skilled swimmers incur no liability for their inaction.

${ }^{20}$ See W. PAge KeEton et AL., Prosser AND KeEton ON THE LAW OF TORTS § 56, at 376-81 (5th ed. 1984); Amy Sinden, Comment, In Search of Affirmative Duties Toward Children Under a Post DeShaney Constitution, 139 U. PA. L. REV. 227, 236 (1990) (discussing affirmative duties in the child welfare agency context).

\footnotetext{
${ }^{21}$ Huefner, supra note 3, at 1948 (footnote omitted).

22489 U.S. 189 (1989).

23 Id. at 191.

${ }^{24}$ Id. at 192 (alteration in original).
} 
The examining physician "suspected child abuse." 25 He notified the Department of Social Services (DSS), which obtained an order from a local court, placing Joshua in the temporary custody of the hospital. The DSS convened an ad hoc "Child Protection Team," including a pediatrician, a psychologist, and a lawyer, "to consider Joshua's situation. ... [T] [Te Team decided that there was insufficient evidence of child abuse to retain Joshua in the custody of the court." 26

The Team did, however, enter into a voluntary agreement with Randy DeShaney designed to protect Joshua. The agreement provided that Mr. DeShaney would enroll Joshua in a preschool program, that Mr. DeShaney would participate in counseling, and that Mr. DeShaney's girlfriend would move out of the house. ${ }^{27}$ Joshua was returned to his father's custody.

One month later Joshua was back in the emergency room. The DSS was again notified that Joshua had been injured, but again concluded that there was no basis for action. ${ }^{28}$

"For the next six months, [a DSS] caseworker made monthly visits to the DeShaney home, during which she observed a number of suspicious injuries on Joshua's head; she also noticed that he had not been enrolled in school, and that the girlfriend had not moved out." 29 The caseworker recorded these observations, but did nothing else. ${ }^{30}$ In November 1983, Joshua was again treated for injuries that were believed to be caused by child abuse and again released to his father. ${ }^{31}$ "On the caseworker's next two visits to the DeShaney home, she was told that Joshua was too ill to see her. Still [the] DSS took no action." 32

"In March 1984, Randy DeShaney beat 4-year-old Joshua so severely that he fell into a life-threatening coma. . . . Joshua did not die, but he suffered brain damage so severe that he is expected to spend the rest of his life confined to an institution.... ${ }^{n 33}$ Joshua's mother filed a Section 1983 suit alleging that the DSS and state officials had deprived Joshua of his substantive due process

${ }^{25} \mathrm{Id}$.

${ }^{26} \mathrm{Id}$.

27 See id.

${ }^{28}$ See id.

${ }^{29} \mathrm{Id}$. at 192-93.

${ }^{30}$ See id. at 193.

${ }^{31}$ See id.

${ }^{32} I d$.

${ }^{33} \mathrm{Id}$. 
rights by failing to intervene to protect him from harm about which they knew or should have known. ${ }^{34}$

The DeShaney Court's holding and its dicta on the issue of when the state assumes an affirmative duty to protect its citizens are, at least on the surface, quite sweeping. The opinion reiterated the general rule that the state is not required to bear affirmative duties, ${ }^{35}$ unless a "special relationship" exists between the individual and the state. The Court stated that this "special relationship" is triggered only "when the State takes a person into its custody and holds him there against his will." ${ }^{36}$

The Court cited the Estelle-Youngberg ${ }^{37}$ line of cases to demonstrate the type of situations where such custody exists. The EstelleYoungberg doctrine refers to the type of custody the state has over involuntarily committed psychiatric patients and prisoners. ${ }^{38}$ The Court conceded that the state has a "duty to assume some responsibility for ... [the] safety and general well-being" of prisoners and the involuntarily committed. ${ }^{39}$

Superficially then, Deshaney seems to set out a clear, simple requirement of "custody" that must be met before the state is held to an affirmative duty to protect a citizen. Subsequent cases and literature regarding DeShaney, however, have been quick to point out that the case is not nearly as lucid as it might seem. While the opinion clearly indicates that the state's relationship to prisoners and the involuntarily committed is "custodial" and will be sufficient to establish an affirmative duty, it does not explicitly state that such conditions are necessary to trigger an affirmative duty. "Judicial attempts to interpret DeShaney suggest that the question of which citizen-state relationships will generate affirmative duties still lacks a definitive answer. ${ }^{\$ 40}$ Essentially, the confusion emanates from two aspects of the opinion: first, the "foster care footnote," and second, the Estelle-Youngberg paradigm.

34 See id. at 191.

35 See id. at 195.

${ }^{36} \mathrm{Id}$. at 199-200 (emphasis added).

${ }^{37}$ See Youngberg v. Romeo, 457 U.S. 307, 317 (1982) (holding that the state has a duty to provide minimal care and services to an involuntarily committed psychiatric patient); Estelle v. Gamble, 429 U.S. 97, 105 (1976) (holding that the government has an affirmative duty to provide needed medical care to incarcerated prisoners).

${ }^{38}$ See DeShaney, 489 U.S. at 199-200.

${ }^{39} \mathrm{Id}$. at 200.

${ }^{40}$ Huefner, supra note 3, at 1948. 
The DeShaney Court in a footnote commented that "[h]ad the State by the affirmative exercise of its power removed Joshua from free society and placed him in a foster home" where he was injured or abused, an affirmative duty might be imposed upon the state's foster care placement agency. ${ }^{41} \mathrm{~A}$ child placed in a foster home selected by a state agency, however, is certainly not being held in the "custody" of the state in any sense that approaches the total incarceration found in prisons or psychiatric institutions. Thus, the foster care footnote arguably vitiates any contention that DeShaney limits affirmative duties only to the strict "custodial" settings of prisons or institutions. Although the majority "express[ed] no view" on whether the state had an affirmative duty to protect children in foster homes since this was not directly at issue, it did leave open the possibility that such a duty could be found. ${ }^{42}$

Additionally, the Court, while superficially requiring "custody" and mentioning prisoners and the involuntarily committed as examples of such custody, did not explicitly state that the EstelleYoungberg contexts exhausted the range of "custodial" situations. The opinion, in fact, offers no clear guidelines to determine if any situation besides prisons or institutions could be deemed custodial. This ambiguity, like the foster care footnote, has been a source of much confusion in attempts to interpret and apply DeShaney. Thus, DeShaney, while at first blush appearing to settle the issue, actually left open the question of what contexts trigger an affirmative duty.

\section{AfFirmative Duty IN Public Schools After DEShaNey: \\ THE FRACTURED APPROACH IN THE LOWER FEDERAL COURTS}

Since the Supreme Court's somewhat murky decision in DeShaney, the lower federal courts have struggled to apply its doctrine in suits against public school officials and districts for their inaction. These cases invariably involve disturbing incidents of physical or sexual abuse of children from pre-school through high school, while in the supposedly secure environs of the public school. Given the moral outrage that often accompanies a review of the "excruciating factual context $[s] " 43$ in these cases, it is perhaps unsurprising that much of the language in these opinions is strongly

41 DeShaney, 489 U.S. at 201 n.9. This footnote is conventionally recognized as the foster care footnote.

$42 I d$.

43 D.R. v. Middle Bucks Area Vocational Technical Sch., 972 F.2d 1364, 1365 (3d Cir. 1992) (en banc), cert. denied, 113 S. Ct. 1045 (1993). 
worded and often eloquent. Unfortunately, the confusion left in the wake of DeShaney has not been overcome by judicial prose. Accordingly, it has been observed that decisions on this issue have resulted in an "unsettling mix of court reactions." 44

\section{A. The Pagano Line of Cases}

Since DeShaney, the lower federal courts have considered a substantial number of cases that have specifically addressed the issue of whether school officials and districts have an affirmative duty to protect students from harm. ${ }^{45}$ Four decisions, Pagano $v$. Massapequa Public Schools, ${ }^{46}$ Robert G. v. Newburgh City School District, ${ }^{47}$ Tilson v. School District, ${ }^{48}$ and Reeves v. Besonen, ${ }^{49}$ were handed down on this issue shortly after DeShaney. They enunciate

44 Valente, supra note 3, at 1021.

45 See, e.g., Dorothy J. v. Little Rock Sch. Dist., No. 92-2452, 1993 WL 406464 (8th Cir. Oct. 13, 1993) (no duty); Black v. Indiana Area Sch. Dist., 985 F.2d 707 (3d Cir. 1993) (no duty); Maldonado v. Josey, 975 F.2d 727, 732 (10th Cir. 1992) ("[W]e agree with the Third and Seventh Circuits and conclude that compulsory attendance laws do not create an affirmative constitutional duty to protect students . . .."), cert. denied, 113 S. Ct. 1266 (1993); Doe v. Taylor Indep. Sch. Dist., 975 F.2d 137 (5th Cir. 1992) (no duty), cert. denied, 113 S. Ct. 1066, reh's granted, 987 F.2d 231 (5th Cir. 1993); D.R. v. Middle Bucks Area Vocational Technical Sch., 972 F.2d at 1364 (no duty); Bonacci v. King, No. 91-3849, 1992 WL 98293 (8th Cir. May 14, 1992) (no duty); J.O. v. Alton Community Unit Sch. Dist. 11, 909 F.2d 267 (7th Cir. 1990) (no duty); D.T. v. Independent Sch. Dist. No. 16, 894 F.2d 1176 (10th Cir.) (found no deliberate indifference so never clearly reached issue of affirmative duty), cert. denied, 498 U.S. 879 (1990); B.M.H. v. School Bd., No. CIV.A.2: 92CV1221, 1993 WL 383559 (E.D. Va. Sept. 23, 1993) (no duty); Doe v. Petaluma City Sch. Dist., No. C-93-0123 EFL, 1993 WL 359872 (N.D. Cal. Aug. 30, 1993) (no duty); Elliott v. New Miami Bd. of Educ., 799 F. Supp. 818 (S.D. Ohio 1992) (no duty); Russell v. Fannin County Sch. Dist., 784 F. Supp. 1576 (N.D. Ga.) (no duty), affd, 981 F.2d 1263 (11th Cir. 1992); Waechter v. School Dist. No. 14 030, 773 F. Supp. 1005 (W.D. Mich. 1991) (duty); Doe v. Douglas County Sch. Dist. RE-1, 770 F. Supp. 591 (D. Colo. 1991) (no duty); Thames v. Kimbrough, No. 91-C-600, 1991 WL 86037 (N.D. Ill. May 15, 1991) (no duty); Reeves v. Besonen, 754 F. Supp. 1135 (E.D. Mich. 1991) (no duty); Tilson v. School Dist., CIV. A. No. 89-1923, 1990 WL 98932 (E.D. Pa. July 13, 1990) (duty in dicta), order affd, 932 F.2d 961 (3d Cir. 1991); Stauffer v. Orangeville Sch. Dist., No. 89-C20258, 1990 U.S. Dist. LEXIS 19133 (N.D. Ill. May 17, 1990) (no duty); Robert G. v. Newburgh City Sch. Dist., No. 89 CIV. 2978 (RPP), 1990 WL 3210 (S.D.N.Y. Jan. 8, 1990) (duty); Pagano v. Massapequa Pub. Sch., 714 F. Supp. 641 (E.D.N.Y. 1989) (duty).

46714 F. Supp. at 641.

${ }^{47}$ No. 89 CIV. 2978 (RPP), 1990 WL 3210 (S.D.N.Y. Jan. 8, 1990).

${ }^{48}$ CIV. A. No. 89-1923, 1990 WL 98932 (E.D. Pa. July 13, 1990), order affd, 932 F.2d 961 (3d Cir. 1991).

49754 F. Supp. at 1135. 
the two basic arguments for finding that these school defendants should be held to an affirmative duty.

The first argument is based on the "foster-care footnote" in Deshaney. The argument goes that even if public school students are not like prisoners or the involuntarily committed, they can be analogized to children placed by the state into foster care. Since DeShaney did not preclude an affirmative duty in the foster care context, a duty should not be precluded in the public school context. The second argument, the Estelle-Youngberg analogy, holds that the prison/institution context and the public school context are analogous and that an affirmative duty should be present in both of these cases. Because the state forces the individual into a psychiatric hospital, a prison, and-through mandatory attendance laws-a school, the state should assume an affirmative duty in all of these situations.

Pagano was the first decision to apply DeShaney in the public school setting. The plaintiff was an elementary school student who claimed that he had been attacked and abused in school by other students on seventeen separate occasions. His Section 1983 claim alleged that school officials had failed to fulfill their affirmative duty to prevent the harm he suffered. ${ }^{50}$ The court referred to several Second Circuit cases in which the Estelle-Youngberg doctrine had been applied to find that the government owed an affirmative duty to the involuntarily committed and to prisoners. ${ }^{51}$ The court then asserted that it "consider[ed] elementary school students who are required to attend school, the truancy laws still being in effect, to be owed some duty of care." 52 The court implicitly reasoned that if the state incurs an affirmative duty to protect a criminal whom the state has "placed" in prison, then a similar duty should also apply to protect a child that has been "placed" in school. State compulsory education and truancy laws were deemed to be the coercive tools of the state used to "place" a child in school. The court adopted the Estelle-Youngberg analogy.

The court also made reference to the foster care footnote in DeShaney, noting that the DeShaney Court did not address "the question of whether a duty exists if [a] child had been placed in a

50 Pagano, 714 F. Supp. at 643.

51 See id. (citing Spence v. Staras, 507 F.2d 554, 557 (7th Cir. 1974) (psychiatric patients) and Villante v. Dep't of Corrections, 786 F.2d 516, 519 (2d Cir. 1986) (prisoners)).

${ }^{52} I d$. 
foster home by [a] state agency and been abused there." ${ }^{\text {53 }}$ The Pagano court cited a Second Circuit decision that held an affirmative duty does exist in the foster care context, ${ }^{54}$ and then stated that "[t]he facts of the present case ... appear to be closer to those of [the foster care situation] than [those] of DeShaney in that the victim and the perpetrator(s) were under the care of the school in its parens patriae capacity at the time these alleged incidents occurred." 55 Using both the Estelle-Youngberg analogy and the foster care footnote approach, the Pagano court provided early support for the claim that an affirmative duty exists in the public school setting under Deshaney. ${ }^{56}$

Robert G. v. Newburgh City School District ${ }^{57}$ followed the same line of reasoning as Pagano. The case involved the sexual assault of a student by a substitute teacher who "had a record of numerous arrests and convictions for crimes, including felonies and other acts of violence. ${ }^{58}$ The court, in denying the defendant's motion to dismiss, did not discuss at length the affirmative constitutional duty of a school district. The court did, however, respond to the defendant's contention that DeShaney precluded liability by stating: "[t]he student had been attending school pursuant to the requirements of New York Education Law ...., and thus was in what may be viewed as functional custody of the school authorities." 59 Like the Pagano court, the Robert G. court adopted the Estelle-Youngberg analogy. The court reasoned that students and prisoners are analogous in that the state has given them no choice but to be in the setting in which they are injured.

The court in Tilson $v$. School District of Philadelphia ${ }^{60}$ offered a more thorough analysis of the affirmative duty required of public

${ }^{53}$ Id. (citing DeShaney v. Winnebago County Dep't of Social Servs., 489 U.S. 189, 201 n.9 (1989)).

${ }^{54}$ See id. (citing Doe v. New York City Dep't of Social Servs., 649 F.2d 134 (2d Cir. 1981)).

${ }^{55} I d$.

56 It should be noted that the opinion in Pagano was a ruling on the defendant school board's motion to dismiss. It was far from a thorough discussion of the issue, but as noted, it did adopt an important line of reasoning. Having survived the motion to dismiss, the case was settled out of court and thus no later opinion exists. Telephone Interview with Henry A. Weinstein, Attorney for the Plaintiff(Dec. 1992).

57 No. 89 CIV. 2978 (RPP), 1990 WL 3210 (S.D.N.Y. Jan. 8, 1990).

${ }^{58}$ Id. at *1.

${ }^{59}$ Id. at *1 (citation omitted) (quoting Stoneking v. Bradford Area Sch. Dist., 856 F.2d 594, 601 (3d Cir. 1988)).

${ }^{60}$ No. CIV A. 89-1923, 1990 WL 98932 (E.D. Pa. July 13, 1990), order affd, 932 F.2d 961 (3d Cir. 1991). 
school officials and school districts after DeShaney. In Tilson, a fouryear-old day care student was sexually molested by a substitute teacher. The court stated that "DeShaney arguably did not foreclose the imposition of a constitutional duty on a school district to provide adequate protection to children while in school. ${ }^{n 1}$ On the facts of the Tilson case itself, however, the imposition of an affirmative duty was deemed inappropriate because preschool attendance is not compulsory in Pennsylvania. ${ }^{62}$ Thus, the requisite element of state coercion required under either the EstelleYoungberg analogy or the foster care footnote approach was wholly absent.

The Tilson court's dicta on the issue of the affirmative duty of public school districts is the most complete coverage of the subject in the series of decisions handed down immediately after DeShaney:

Arguably [the view] that students are in what may be viewed as functional custody of the school authorities' during their presence at school because they are required to attend under Pennsylvania law ... is not inconsistent with the DeShaney opinion. Dicta in DeShaney, that a state might be liable for a substantive due process violation for failing to prevent foster parents' abuse of a foster child placed in their custody by the state, leaves open the question of a school's constitutional duty to provide adequate protection to a student with whom it has a special custodial relationship. Based on DeShaney's suggestion that a child placed in foster homes may be more akin to an institutionalized or incarcerated person than a child remaining in parental custody ... the child subject to compulsory school attendance "may not be dissimilar" to a child placed in a foster home. ${ }^{63}$

Thus, the court identified both the Estelle-Youngberg analogy and the foster care footnote approach. ${ }^{64}$

${ }^{61} I d$. at *3 (citing Stoneking v. Bradford Area Sch. Dist., 882 F.2d 720, 723-24 (3d Cir. 1989) [hereinafter Stoneking $I I])$.

62 See id. at *9.

${ }^{63}$ Id. (citations omitted) (quoting Stoneking II, 882 F.2d at 723-24).

${ }^{64}$ Interestingly, the court made the following comment about the situation of young children not mandated by law to attend school:

Preschool attendance is not compulsory in Pennsylvania [until age eight]. . . . Participation in a Get Set [day care] program [in which plaintiff was enrolled] is voluntary; parents choose to place their children in day care. However, the tender years of preschool children . . . favor[s] imposing the same constitutional duty to provide for their reasonable safety as for institutionalized or incarcerated individuals. 
In Reeves $v$. Besonen, ${ }^{65}$ the court considered the claim of a high school football player who was injured by fellow players during a hazing incident on the team bus. ${ }^{66}$ As in Tilson, the plaintiff was not covered by the state compulsory education law when he was injured because the football team trip was an extracurricular and wholly voluntary activity. ${ }^{67}$ Although Reeves seems to disallow the imposition of an affirmative duty in contexts other than prisons or psychiatric institutions, ${ }^{68}$ there is language which recognizes a different interpretation of DeShaney. The court deemed relevant the fact that the compulsory education law did not apply, stating that "[i]n the absence of such State coercion, DeShaney makes clear that the Constitution imposes no duty on the state to care for the Plaintiff's safety. ${ }^{169}$ The court thus permitted the inference that if the necessary "coercion" did exist, a duty could be triggered even if the injury did not occur in a prison or psychiatric institution, but rather in a public school. Here too the court seems to accept the rationale of the Estelle-Youngberg analogy.

While DeShaney, at least on a superficial read, arguably precludes the imposition of an affirmative duty on the state unless the state has used its coercive power to place a citizen in a prison or institution, the courts that issued the opinions discussed in this Section did not read DeShaney so narrowly. An affirmative duty was found in the public school setting. Either the public school context was deemed analogous to the prison or psychiatric institution by virtue

Id. (citation omitted). The court here seems to adopt a more expansive view of when an affirmative duty should be triggered. It completely abandons the dogma that asserts that the duty-triggering "special relationship" must be based on at least some degree of state compulsion. This commentary by the court was purely academic, however, because it found that "even if there were a duty, it is clear on the record before the court that the conduct of the school district . . . did not exhibit deliberate indifference to protecting children within their care from sexual abuse." Id.

65754 F. Supp. 1135 (E.D. Mich. 1991).

${ }^{66}$ See id. at $1136-38$.

67 See id. at 1140 .

68 The court used particularly grandiose language in this context:

The Constitution of the United States is, and must be, a document of grandeur and wisdom which secures and protects the most fundamental and sacrosanct rights of our people. To extend the protections of the Constitution to the most mundane fracases of everyday life cheapens and trivializes not only the Constitution itself, but those rights and privileges which are protected under it, as well.

Id. at 1141 n.2.

${ }^{69} \mathrm{Id}$. at 1140. 
of the element of state coercion (the Estelle-Youngberg analogy), or it was deemed sufficiently parallel to the foster care situation (the "foster care footnote" approach).

\section{B. Cases that Rejected the Pagano Approach}

Soon after Pagano, however, a number of decisions were issued which made clear that most lower federal courts were reading DeShaney more strictly. Many courts reasoned that DeShaney completely ruled out affirmative duties in any context except involuntary institutionalization and imprisonment. Taking a slightly less rigid approach, other courts did not explicitly state that the Estelle-Youngberg contexts are the only situations where the state incurs an affirmative duty, but they rejected the notion that public schools are sufficiently analogous to Estelle-Youngberg. Whatever their rationale, by denying the existence of an affirmative duty in the public schools, the decisions discussed below stand in direct contradiction to the Pagano line of cases.

In J.O. v. Alton Community Unit School District $11,{ }^{70}$ the Seventh Circuit considered a Section 1983 claim against a school district for failing to protect the plaintiffs against sexual molestation by a teacher. The court flatly stated that "[s]choolchildren are not like mental patients and prisoners such that the state has an affirmative duty to protect them," and noted that beyond those specific contexts, "the Supreme Court has never recognized such a duty. ${ }^{71}$ The claim that the compulsory education law in Illinois made school children analogous to prisoners or involuntarily committed psychiatric patients was clearly refuted. The court stated that, " $[\mathrm{a}] \mathrm{t}$ most, the state might require a child to attend school, but it cannot be suggested that compulsory school attendance makes a child unable to care for basic human needs," ${ }^{72}$ as is the case with prisoners or involuntarily committed psychiatric patients.

The Eighth and Tenth Gircuits also rejected an affirmative duty in the public school context. In Bonacci $v$. King, ${ }^{73}$ the Eighth Circuit bluntly dismissed the claim of a student who had been sexually abused in his high school. The court stated: "We reject [the] contention that [t]his case falls within an exception to the

\footnotetext{
70909 F.2d 267 (7th Cir. 1990).

${ }^{71} \mathrm{Id}$. at 272-73.

72 Id. at 272 (citation omitted).

${ }^{73}$ No. 91-3849, 1992 WL 98293 (8th Cir. May 14, 1992).
} 
general rule pronounced in DeShaney; the only exception recognized in that case, arising when a state has custody over the injured individual, is not applicable in this instance. ${ }^{74}$ In Maldonado $v$. Josey, ${ }^{75}$ the Tenth Circuit stated: "Under DeShaney, an affirmative duty to protect arises only when the state 'so restrains an individual's liberty that it renders him unable to care for himself ...' This type of restraint ... does not occur under New Mexico compulsory attendance laws. ${ }^{\prime 76}$

Thames v. Kimbrough ${ }^{77}$ involved a student who was shot in school when another student's handgun accidentally fired as he was removing it from his school bag. In response to the plaintiff's affirmative duty to protect claim, the court simply stated that DeShaney 'stands for the 'harsh proposition' that even when state officials know that a person is in imminent danger of harm from a third party ... the [Constitution] 'imposes upon those state officials no obligation to prevent that harm."n78 The plaintiff's complaint was accordingly dismissed. ${ }^{79}$

The court in Doe v. Douglas County School District $R E-1,{ }^{80}$ dealing with a school psychologist who allegedly molested a high school student, was similarly curt in dismissing the claim that the school's officials had any affirmative duty to protect the plaintiff from harm. Citing DeShaney and Alton, the court pronounced that, unlike the condition of prisoners or involuntarily committed psychiatric patients,

"[i]t cannot be suggested that compulsory school attendance makes a child unable to care for basic human needs. The parents still retain primary responsibility for feeding, clothing, sheltering, and caring for the child."

... [A]s a matter of law ... plaintiff cannot rely on the existence of a special relationship to hold Douglas County [school officials] liable. ${ }^{81}$

74 Id. at *1. A more thorough discussion by the Eighth Circuit (reaching the same conclusion) can be found in Dorothy J. v. Little Rock Sch. Dist., No. 92-2452, 1993 WL 406464 (8th Cir. Oct. 13, 1993).

75975 F.2d 727 (10th Cir. 1992).

${ }^{76}$ Id. at 732 (quoting DeShaney, 489 U.S. at 200).

77 No. 91-C-600, 1991 WL 86037 (N.D. Ml. May 15, 1991).

${ }^{78} \mathrm{Id}$. at *2 (quoting Horton v. Flenory, 889 F.2d 454, 457 (3d Cir. 1989)).

${ }^{79}$ See id. at *3.

80770 F. Supp. 591 (D. Colo. 1991).

${ }^{81}$ Id. at 593-94 (quoting J.O.v. Alton Community Unit Sch. Dist. 11, 909 F.2d 267, 272 (7th Cir. 1990)). 
In Russell v. Fannin County School District, ${ }^{82}$ one student assaulted another student in the hallway of the school building during school hours, breaking the other student's hand, fracturing his left orbit, and damaging his eye. The court denied the existence of an affirmative duty on the part of the state. ${ }^{83}$ Instead of simply citing the Estelle-Youngberg doctrine as support for applying an affirmative duty only in prisons or institutions, the court elaborated:

The state must somehow significantly limit an individual's freedom or impair his ability to act on his own before it can be constitutionally required to care and provide for that person.

The court is not suggesting that prisoners and mental patients are an exhaustive list of all persons to whom the state owes some affirmative duties, but the government ... has not rendered its students so helpless that an affirmative constitutional duty to protect arises. ${ }^{84}$

Although the court here rejects the Estelle-Youngberg analogy, it does not adopt the more stringent view that Estelle-Youngberg situations are the only instances in which affirmative duties may be applied.

The court in Elliott $v$. New Miami Board of Education ${ }^{85}$ reviewed the conflicting opinions of other courts and sided with those decisions that refused to confer an affirmative duty upon public school officials. The idea that school children's situations could be analogized to those of prisoners was not accepted. The court responded to the suggestion by arguing that the comparison "of a school yard to a prison may be a popular one for school-age children, but we cannot recognize constitutional duties on a child's lament." 86 Similarly brusque language was used by the court in Stauffer $v$. Orangeville School District. ${ }^{87}$ The court argued that if a duty was imposed, then "every time a school child [was] assaulted by the class bully during recess there would be a tort of constitutional dimensions under 1983. ${ }^{88}$

82784 F. Supp. 1576 (N.D. Ga.), affd, 981 F.2d 1263 (11th Cir. 1992).

${ }^{83}$ See id. at 1583 .

${ }^{84}$ Id. at 1582 (citation omitted) (quoting Wideman v. Shallowford Community Hosp., Inc., 826 F.2d 1030, 1036 (11th Cir. 1987)).

85799 F. Supp. 818 (S.D. Ohio 1992).

${ }^{86}$ Id. at 822 (quoting Alton Community Sch. Dist., 909 F.2d at 272-73). Other district court cases finding no duty are: B.M.H. v. The Sch. Bd., 1993 WL 383559 (E.D. Va. Sept. 23, 1993) (no duty); Doe v. Petaluma Sch. Dist., No. C 930123 EFL, 1993 WL 359872 (N.D. Cal. Aug. 30, 1993).

871990 U.S. Dist. LEXIS 19133 (N.D. Ill. May 17, 1990).

${ }^{88} \mathrm{Id}$. at 14. 
Thus, it appeared that the lower federal courts were "beginning to fall into line in deciding that public school officials have no constitutional duty to protect students from harm. ..."89 As will be seen in Part C, however, the dispute is still alive and well.

\section{The Split in the Circuits}

Two recent decisions on this issue, Doe v. Taylor Independent School District ${ }^{90}$ and D.R. v. Middle Bucks Area Vocational Technical School, ${ }^{91}$ demonstrate that the courts' fractured approach has not been resolved, and that the tension between the two competing views continues to divide the judiciary. These cases also establish a direct split on this issue at the appellate level, not just within the district courts.

Doe v. Taylor, decided by the Fifth Circuit in October 1992, is notable not only for reviving the imposition of an affirmative duty but also for its eloquent and forceful language. ${ }^{92}$ Judge Goldberg began his opinion with the following statement:

You would think it obvious that sexual molestation, when visited upon one of our schoolchildren ... would undoubtedly violate her constitutional right to be free from intrusions into bodily integrity. You would also think it indisputable that a school superintendent and a school principal, once aware that such reprehensible conduct was taking place on their campus, would have not only a moral duty, but also a legal duty, to stop it-that the Constitution would not tolerate their looking the other way ....

${ }^{89}$ Summary and Analysis: Schools Have Constitutional Duty to Protect Students from Sexual Abuse, 61 U.S.L.W. 1062, 1062 (Nov. 3, 1992).

90 975 F.2d 137 (5th Cir. 1992), cert. denied, 113 S. Ct. 1066, reh'g granted, 987 F.2d 231 (5th Cir. 1993).

91 972 F.2d 1364 (3d Cir. 1992) (en banc), cert. denied, 113 S Ct. 1045 (1993).

92 While all of the cases that involve instances of sexual or physical abuse of a student by a teacher or school employee are shocking and saddening, the facts of the Doe case are particularly noteworthy. The acts committed are not any more egregious than those of the other cases, but the "indifference" of the school officials in this case seems to rise to a level greater than any of the other ones. The "romantic relationship" between the teacher and student in this case "was common knowledge within the Taylor High community, not only among students, but also among parents and faculty." Doe, $975 \mathrm{~F} .2 \mathrm{~d}$ at 140 . This particular teacher "made little effort to conceal his fancy for his female students, writing explicit love notes to them, letting them drive his truck, exhibiting explicit favoritism in class toward them, and physically touching them in a manner not becoming a schoolteacher." Id. at 139. Several reports were made to school officials; however, no one ever made any effort to protect the plaintiff. 
We hold that ... the [school officials] had an affirmative, constitutionally-based duty to protect her . . . .93

The opinion cited two pre-DeShaney Fifth Circuit cases-Horton v. Goose Creek Independent School District ${ }^{94}$ and Lopez v. Houston Independent School District ${ }^{95}$-which state that a public school assumes a duty to protect school children from "harm posed by antisocial activities." ${ }^{\text {96 }}$ The Doe opinion then launched into a discussion of the circumstances where a "special relationship" arises that will trigger an affirmative duty:

A special relationship between the state and a child arises in a variety of contexts: when a child is confined to a state mental health facility; when a state social services agency removes a child from his natural home and places him under state supervision; or when a child has been placed in foster care. In these instances, the state has, to varying degrees, assumed an obligation to protect the child, in much the same way that a capable parent would. A child generally depends on his parents to guard against the dangers of his surroundings. This is a fundamental notion of our organized society and at the heart of what many would dub "family values." By removing the child from his home, even when the child's best interests lie in such action, the state thereby obligates itself to shoulder the burden of protecting the child from foreseeable trauma. . . .

... [B]y compelling a child to attend public school, the state cultivates a special relationship with that child and thus owes him an affirmative duty of protection. Although we too would not equate "a school yard to a prison," we nevertheless find a schoolchild to be in the "functional custody" of school officials."

Thus, the Fifth Circuit adopted the view of the earlier Pagano line of decisions.

In direct contradiction to the Fifth Circuit's Doe v. Taylor decision is the August 1992 Third Circuit opinion in D.R. v. Middle Bucks Area Vocational Technical School. ${ }^{98}$ The plaintiffs in the D.R. case were two female students in a high school graphics art class who alleged that several of their male classmates physically, verbally,

\footnotetext{
${ }^{93} I d$. at 138.

94690 F.2d 470 (5th Cir. 1982), cert. denied, 463 U.S. 1207 (1983).

95817 F.2d 351 (5th Cir. 1987).

${ }^{96} I d$. at 356 (quoting Horton, $690 \mathrm{~F} .2 \mathrm{~d}$ at 480 ).

97 Doe, 975 F.2d at $146-47$ (footnotes and citation omitted).

${ }^{98} 972$ F.2d 1364 (3d Cir. 1992) (en banc), cert. denied, 113 S. Ct. 1045 (1993).
} 
and sexually molested them. ${ }^{99}$ They were forced by their classmates into a unisex bathroom and a darkroom, both of which were part of the classroom. ${ }^{100}$ The teacher in the graphic arts class "admittedly experienced difficulty in controlling the class generally."101 She "witnessed daily the chaotic behavior that took place in her classroom and was present when the male students grabbed at D.R., touched her breasts, pushed her down, and dragged her into the bathroom. The teacher's general reaction was to ignore the behavior or walk away." 102 Although a report was allegedly made to the Assistant Director of the school, none of the school officials intervened. ${ }^{103}$

As the court phrased the issue, it had to determine if the compulsory education law and the school's in loco parentis authority created a "custody" situation sufficiently akin to a prison or psychiatric institution. The court rejected this contention flatly: "Our court has read DeShaney primarily as setting out a test of physical custody. ... [T] [Te school defendants' authority over D.R. during the school day cannot be said to create the type of physical custody necessary to bring it within the special relationship noted in DeShaney ...."104 The court made efforts to distinguish the public school situation from the Estelle-Youngberg context:

The state's duty to prisoners and involuntarily committed patients exists because of the full time severe and continuous state restriction of liberty in both environments. Institutionalized persons are wholly dependant upon the state for food, shelter, clothing and safety. It is not within their power to provide for themselves, nor are they given the opportunity to seek outside help to meet their basic needs. Obviously, they are not free to leave.

... [Conversely,] public school parents retain the discretion to remove the child from classes as they see fit ... ${ }^{105}$

The court also addressed the argument that public schools are akin to foster care:

${ }^{99}$ See id. at 1366.

100 See id.

101 Id.

102 Id. at 1378 (Sloviter, C.J., dissenting) (citation omitted).

103 See id. at 1366.

${ }^{104}$ Id. at $1370,1372$.

${ }^{105}$ Id. at 1371 (citations omitted). 
[W]e do note that although the situation of a public school student is perhaps closer to that of a foster child than to an institutionalized person, the foster care analogy is not decisive.

A relationship between the state and foster children arises out of the state's affirmative act in finding the children and placing them with state-approved families. By so doing, the state assumes an important continuing, if not immediate, responsibility for the child's well- being. In addition, the child's placement renders him or her dependent upon the state, through the foster family, to meet the child's basic needs. Students, on the other hand, do not depend upon the schools to provide for their basic human needs. ${ }^{106}$

Chief Judge Sloviter authored a powerfully worded dissent:

I believe that we are free to decide, as I would hold, that the state compulsion that students attend school, the status of most students as minors whose judgment is not fully mature, the discretion extended by the state to schools to control student behavior, and the pervasive control exercised by the schools over their students during the period of time they are in school, combine to create the type of special relationship which imposes a constitutional duty on the schools to protect the liberty interests of students while they are in the state's functional custody.

....

... In this case, unlike DeShaney, the harm was inflicted while the victim was in the state's custody and/or care. ${ }^{107}$

Chief Judge Sloviter insisted that nothing in the DeShaney opinion supported the majority's holding that "the duty to protect can be triggered only by involuntary, round-the-clock, legal custody. Nothing in the opinion suggests that compulsory school attendance cannot qualify as the type of state restraint of personal liberty which gives rise to a duty to protect. ${ }^{108}$ She cited the foster care footnote as supporting her claim that DeShaney was being read too narrowly by the majority. ${ }^{109}$

${ }^{106} I d$. at 1372 (citations omitted).

${ }^{107} I d$. at 1377, 1379 (Sloviter, C.J., dissenting). Sloviter also argued that "[a]lthough a student is not held in school under shackles, there is substantial compulsion associated with schooling." Id. at 1379. Sloviter noted that "[ $t]$ he compulsory nature of public school attendance is not lessened by the fact that a few fortunate students have the option to attend private school or be educated at home. For the vast majority of children of school age, this is no choice at all." Id. at 1380. ${ }^{108}$ Id. at 1379.

${ }^{109}$ See id. 
Having criticized the majority's use of DeShaney, Chief Judge Sloviter then emphasized that most "secondary school students are minors ... [whose] judgment may not be fully mature" and that state law confers in loco parentis authority upon public schools. ${ }^{110}$

The dissent concluded:

The majority's restrictive view of the "special relationship" ... is particularly troubling, not only because it is based on the erroneous premise that its decision is compelled by precedent but also because it is so sweeping that it is unlikely that any state-imposed restraint of personal liberty short of incarceration or involuntary commitment will trigger the duty to protect....

There is no doubt that this case falls between DeShaney and Estelle/Youngberg. ${ }^{111}$

As Doe v. Taylor and D.R. v. Middle Bucks Vocational Technical School indicate, the battle in the courts over affirmative duties in public schools was joined by the Fifth and Third Circuits. Because the Supreme Court recently denied petitions for certiorari in both of these cases, it appears that this sensitive issue will continue to plague the judiciary. 112

\section{WhEN the State Should Have an AfFiRMative Duty TO PRotect A GrTIZEN}

Clearly, courts need to draw some lines when imposing affirmative duties on the state. Holding the state liable for its inaction "poses very serious difficulties," Judge Posner notes, because " $[t]$ he men who wrote the Bill of Rights were not concerned that government might do too little for the people but that it might do too much to them. ${ }^{n 13}$ Courts have repeatedly emphasized that the Bill of Rights does not confer affirmative rights to governmental assistance, but is rather a charter of negative liberties. These writings point out that the Bill of Rights prevents the state from doing something to an individual, but does not guarantee that the state will do for her. ${ }^{114}$

$110 I d$. at 1380 .

111 Id. at 1383.

112 See D.R. v. Middle Bucks Area Vocational Technical Sch., 113 S. Ct. 1045 (1993) (denial of certiorari) and Caplinger v. Doe, 113 S. Ct. 1066 (1993) (denial of certiorari).

113 Sinden, supra note 20, at 230 (quoting Jackson v. City of Joliet, 715 F.2d 1200, 1203 (7th Cir. 1983) (citations omitted), cert denied, 465 U.S. 1049 (1984)).

${ }^{114}$ See Michael J. Florio, Note, An Abused Child's Right to Life, Liberty and Property 
This principle of constitutional construction aside, concerns surrounding the "[d]iscretionary [a]llocation of [p]ublic [r]esources"115 create strong arguments for limiting the instances in which the state incurs an affirmative duty to protect a citizen. In a society where government resources are scarce, and difficult choices must be made about how best to allocate those resources, courts and commentators persuasively argue that the more politically responsive executive and legislative branches are better equipped than the courts to make those budgetary choices. ${ }^{116}$

There is also a more general fear that the imposition of affirmative duties will lead to the creation of "big government," with unlimited power in society. This concern is evident in cases involving police officers and firefighters. Although the concept may seem counter-intuitive, as a general matter, police officers and firefighters have no affirmative duty to protect citizens from harm. In Jackson $v$. City of Joliet, ${ }^{117}$ the court held that a police officer who came upon an automobile accident had no duty to look for or rescue a person trapped in the car. The opinion expressed concern that "the next case ... will be one where the police and fire departments, maybe because of budget cuts, do not arrive at the scene of the accident at all." 118 The court reasoned that holding the police or firefighters liable would be totally unacceptable because it would force municipalities to supply endless funds for its service providers. The court forcefully warned against any argument that could lead to a general constitutional duty to "provide basic services."119

These concerns about separation of powers and "big government" should be somewhat mitigated by the fact that any affirmative duty on the part of the state would be an exception to the rule that the state has no duty to rescue its citizens. ${ }^{120}$ Again, as a general

in the Home: Constitutional Approval of State Inaction, 92 W. VA. L. REv. 175, 195 (1989).

115 Thomas A. Eaton \& Michael L. Wells, Governmental Inaction as a Constitutional Tort: DeShaney and its Aftermath, 66 WASH. L. REV. 107, 128 (1991).

${ }^{116}$ See, e.g., id. at 128-29; Riss v. City of New York, 240 N.E.2d. 860, 860-61 (N.Y. 1968) ("For the courts to proclaim a new and general duty of protection . . . could and would inevitably determine how ... limited . . . resources should be allocated ....").

117715 F.2d 1200 (7th Cir. 1983), cert. denied, 465 U.S. 1049 (1984).

118 Id. at 1204.

119 Id. at 1203-04.

120 See Eaton \& Wells, supra note 115 , at 109; supra note 19 and accompanying text. 
matter, the affirmative duty is applied only in circumstances where the state has entered into a "special relationship" with the citizen. ${ }^{121}$ Yet even within this exception, there are legitimate concerns about avoiding the imposition of an affirmative duty in too many situations, and lines must be drawn.

On the surface, it would appear that the most easily implemented test would be to limit the imposition of an affirmative duty strictly to the contexts of prisons and institutions-a stringent EstelleYoungberg doctrine. Commentators have noted, however, that "limiting affirmative duties to instances of involuntary confinement or analogues of confinement is arbitrary and unwise. ${ }^{122}$ As Professors Eaton and Wells explain:

One important test of a liability rule is whether it reaches the full range of cases in which recovery is appropriate, or at least an acceptably large portion of them. The involuntary confinement rule fails on this score, for it falls short of embracing all instances of official misconduct impinging a plaintiff's constitutionally protected right to respectful treatment by government officers. ${ }^{123}$

Specific examples of the type of cases that would be "missed" by an Estelle-Youngberg rule are considered below. It is important to note here, however, that even the DeShaney Court, a court clearly opposed to expanding constitutional liability for inaction, purposely avoided such a limited approach by leaving open the question of foster care. ${ }^{124}$

Another possible approach to liability for state inaction would be to limit affirmative duties to situations where the state has undertaken "legal custody" of the victim. However, "the ambiguity inherent in the term "custody' raises significant problems when attempting to apply such a test. ${ }^{125}$ "Custody," it turns out, is a very "malleable" term in the law. ${ }^{126}$ For example, in Horton $v$. Flenory ${ }^{127}$ the police knew that a private club owner (an ex-policeman) was questioning a man about a recent incident at the club and

121 DeShaney is unanimously read as "foreclos[ing] the argument that there is a general constitutional right to protection." Eaton \& Wells, supra note 115, at 158.

122 Id. at 111.

123 Id. at 144 .

124 See supra note 41 and accompanying text.

125 Sinden, supra note 20, at 247.

$126 \mathrm{Id}$. at 250.

127889 F.2d 454 (3d Cir. 1989). 
condoned the owner's actions. ${ }^{128}$ The club owner ended up beating the man to death during the course of his "questioning." The court held that the plaintiff's decedent had been in "custody" at the time of his death for purposes of an affirmative duty analysis. ${ }^{129}$ Thus, the concept of custody is not as straightforward as it may appear.

As one commentator remarked:

The meaning of the word "custody" varies significantly depending upon the context in which it is used. Asking whether someone is in "custody" in a Miranda case is entirely different from asking whether a child is in "custody" in the context of a domestic relations dispute. "Custody" does not in and of itself clearly designate a specific set of parameters . . . . ${ }^{130}$

Both a "legal custody" test or a strict Estelle-Youngberg test would be plagued by significant shortcomings. There are a variety of circumstances outside of either the Estelle-Youngberg context, or any circumstance that may reasonably be deemed "custodial," where it would seem wholly appropriate to impose an affirmative duty. Indeed, lower courts have not hesitated to do so. For example, in Wood $v$. Ostrander, ${ }^{131}$ a woman was abandoned by police in a desolate area, late at night, after they had confiscated her car and arrested her companion. ${ }^{132}$ The woman was subsequently attacked and raped by a stranger. ${ }^{133}$ Clearly, there was an intervening actor, but it can nevertheless safely be said that the state "caused" the woman's "predicament."134 The Ninth Circuit held that the police conduct toward the plaintiff "distinguishes [her] from the general public and triggers a duty of the police to afford her some measure of peace and safety. ${ }^{135}$ Consider the Seventh Circuit's opinion upholding liability for inaction in White $v$. Rochford. ${ }^{136}$ In White, the police had stopped a car on an expressway

${ }^{128}$ See id. at 456 .

${ }^{129}$ See id. at 458. Some cases, however, have construed "custody" more strictly. See, e.g., Milburn v. Anne Arundel County Dep't of Social Servs., 871 F.2d 474 (4th Cir.) (construing "custody" to refer to the narrow relationship of child and foster parents), cert. denied, 493 U.S. 850 (1989).

130 Sinden, supra note 20 , at 248.

131879 F.2d 583 (9th Cir. 1989), cert. denied, 498 U.S. 938 (1990).

132 See id. at 586 .

133 See id.

${ }^{134}$ See Rosalie B. Levinson, Protection Against Government Abuse of Power: Has the Court Taken the Substance Out of Substantive Due Process?, 16 U. DAYTON L. REV. 313, 341 (1991).

135 Wood, 879 F.2d at 590.

136592 F.2d 381 (7th Cir. 1979); see also Eaton \& Wells, supra note 115, at 144 
and arrested the driver for drag racing and speeding. ${ }^{137}$ The driver repeatedly requested that the police call for assistance, but the officers left the driver's child passengers alone in the car. ${ }^{138}$ One of the children had asthma, became very ill, and was hospitalized for over a week after the incident. ${ }^{139}$ The Seventh Circuit held that the children stated a valid Section 1983 claim. ${ }^{140}$

These fact patterns are certainly distinguishable from a prison or psychiatric institution situation, and do not resemble "custody" in any meaningful way. Nevertheless, "[e]ven judges who are generally hostile to the expansion of affirmative duties now agree that the plaintiffs ... stated a good constitutional tort case."141 Commentators have noted that "the difference between placing a person in custody and using state authority to leave him stranded in a dangerous place seems too insubstantial to support a rule that would permit liability in the former case but not the latter." 142 If courts limited the imposition of affirmative duties to prisons, institutions, and other arguably "custodial" situations, many plaintiffs who have clearly suffered at the hands of the state's abusive behavior would be without recourse under Section 1983.

The affirmative duty issue poses the following question to the courts: "If the Constitution [or federal law] sometimes ... require[s] government officials to help persons in distress, what circumstances trigger a duty to act?"143 The courts' doctrinal analysis is overtly concerned with categorizing situations (i.e., prisons, institutions, foster care). The underlying principle behind this categorization, however, has been identified by commentators and has been explicitly noted by some courts. This Comment suggests that the principle can be articulated as follows: The state should be held to an affirmative duty when the state has coerced the citizen into a situation in which she is vulnerable to harm (or at least more vulnerable than she would have been outside of that situation) and, in particular, where the state has put the citizen in a situation where access to assistance is difficult to obtain. This

(discussing White).

${ }^{137}$ See White, 592 F.2d at 382.

138 See id.

139 See id.

140 See id. at 384-86.

141 Eaton \& Wells, supra note 115, at 144-45 (referring to Judge Easterbrook and Judge Posner).

I42 Id. at 144.

143 Id. at 107. 
Comment argues that these concerns, instead of the current categorical approach, should be the direct focus of judicial inquiry.

When courts decide affirmative duty cases by asking whether a particular situation is like a prison, psychiatric institution, or other "custodial" situation, they frequently involve themselves in the fruitless task of attempting to draw "coherent analog[ies]."144 It is difficult to say with any certainty whether a "school yard is like a prison ${ }^{145}$ or whether a child placed in foster care is like a child placed in a classroom. Analogous elements exist in each situation, but any definitive statement that they are "alike" or "dissimilar" is almost always an oversimplification. By focusing instead on the degree of vulnerability and ability to seek assistance, a court's inquiry would be more relevant to identifying when the state has "significantly contribute[d] to the plaintiff's need for assistance, ${ }^{146}$ and thus should be held to an affirmative duty.

Professors Eaton and Wells argue for an analysis of constitutional affirmative duties that recognizes the various ways in which the state plays a role in making someone vulnerable to harm. ${ }^{147}$ Eaton and Wells assert that constitutional liability for government inaction should be based on an inquiry into the degree of state involvement in producing the plaintiff's plight. ${ }^{148}$

Another commentator who directly examined the issue of affirmative duties in the public school context (but did so prior to the two most recent and thorough appellate level decisions on this point) noted that it is "not the state's legal status as custodian" which should trigger the obligation for affirmative action. ${ }^{149}$ The author criticized the idea of basing an affirmative duty on any overly formalistic conception of the state-victim relationship:

Although the formal relationship may serve as an indicator of the underlying vulnerability and of the victim's corresponding dependency on the state for protection, it is only an indicator. Courts ... should be concerned principally with the extent to which the state, by limiting the victim's freedom or by taking upon itself the responsibility for some of her care, increases the victim's dependence on state protection. Affirmative duties should exist whenever the state has created this dependency, regardless of

144 Id. at 146.

145 J.O. v. Alton Community Sch. Dist. 11, 909 F.2d 267, 273 (7th Cir. 1990).

146 Eaton \& Wells, supra note 115, at 111.

147 See id. at 108-11 (emphasis added).

148 See id. at 111 .

149 Huefner, supra note 3, at 1957. 
whether it arises out of a relationship that is technically custodial. This type of dependency could be found to be associated with youths in foster care, with school children, or with individuals detained by private citizens informally deputized as police officers. ${ }^{150}$

The two most recent appellate level decisions dealing with the affirmative duty question in the public school context offer the most extensive discussion of its underlying principles. By closely examining the court's commentary, it becomes apparent that the courts do recognize that the vulnerability of the victim and her access to assistance are, at bottom, the central concerns in determining when the state should be held to an affirmative duty.

In Doe v. Taylor, the court acknowledged that children's inability to care for themselves is generally taken for granted in our society and that their well-being is entrusted to their parents or guardians. ${ }^{151}$ Given that assumption, if the state, through compulsory education laws, separates children from their "protectors" for any period of time, the state leaves children vulnerable and "incapable of fending for [themselves]."152 The Taylor court stated that an affirmative duty should be imposed because the state substantially hindered the child's access to a source of assistance she would ordinarily call upon-her parent or guardian. By "render[ing] the guardian ... powerless to act on the child's behalf[,] . . . the state assumes a corresponding duty." 153

The dissent in D.R. v. Middle Bucks Area Vocational Technical School is the clearest expression of the focus on vulnerability and access to outside assistance:

[T]he School District cannot claim that it did not play some role in creating the danger to D.R. or making her more vulnerable. Here, it was the school that designed the unisex lavatory in the classroom; .... it was the school that hired an inexperienced student teacher; and it was the school that tolerated the chaotic behavior and the sexual aggressiveness of the students. ...

Thus, in this case I would find that the plaintiffs have sufficiently pled facts alleging a breach of duty to protect triggered

150 Id. (emphasis added).

151 See Doe v. Taylor Indep. Sch. Dist., 975 F.2d 137, 146 (5th Cir. 1992), cert. denied, 113 S. Ct. 1066 (1993) ("A child generally depends on his parents to guard against the dangers of his surroundings.").

152 Id.

${ }^{153} I d$. 
by the special relationship that arises between vulnerable school children and their public schools. ${ }^{154}$

The dissent also chastised the majority for insisting that schoolchildren, unlike prisoners, "have meaningful access to sources of help. "155 After noting that truancy laws would expose children to punishment if they left the school, that school authorities typically would not allow a parent or guardian to attend classes with a child to assure her safety, and that children are generally reluctant to report sexual abuse, ${ }^{156}$ Chief Judge Sloviter stated that ${ }^{~}[t] h e r e$ is, at least, a factual issue presented in this case as to whether D.R. was in a position effectively to seek help."157

Although the majority in $D . R$. refused to find a special relationship in the public school setting, they too recognized the importance of examining the victim's access to outside assistance. The court stated that a special relationship exists when "the State, by the affirmative exercise of its power so restrains an individual's liberty"158 that she is "left without reasonable means of self protection." 159

The decision in Russell also indicates that the vulnerability of the victim and her access to assistance are the relevant concerns:

[A] constitutional duty can arise only when a state or municipality, by exercising a significant degree of control over an individual, places that person in a worse situation than he would have been had the government not acted at all. Such a situation could arise by virtue of the states affirmatively placing an individual in a position of danger, effectively stripping a person of her ability to defend herself or cutting off potential sources of private aid. ${ }^{160}$

${ }^{154}$ D.R. v. Middle Bucks Area Vocational Technical Sch., 972 F.2d 1364, 1382 , 1384 (3d Cir. 1992) (en banc) (Sloviter, C.J., dissenting) (emphasis added), cert. denied, 113 S. Ct. 1045 (1993).

$155 \mathrm{Id}$. at 1381 .

${ }^{156}$ See id. at 1380-81. Note that Chief Judge Sloviter also stated that "prisoners are probably much more articulate about their complaints about mistreatment than are school children, particularly when the treatment consists . . of sexual abuse." Id. at 1381.

${ }^{157} I d$.

${ }^{158}$ Id. at 1370 (citing DeShaney v. Winnebago County Dep't of Social Servs., 489 U.S. 189,200 (1989)).

${ }^{159} I d$.

160 Russell v. Fannin County Sch. Dist., 784 F. Supp. 1576, 1582 (N.D. Ga.) (citing Wideman v. Shallowford Community Hosp., Inc., 826 F.2d 1030, 1035 (11th Cir. 1987)), affd without opinion, 981 F.2d 1263 (11th Cir. 1992). 
In Archie v. City of Racine, ${ }^{161}$ the Seventh Circuit had this to say about relying on a categorical "special relationship" analysis to determine when the state incurs an affirmative duty:

Like other legal phrases, [the term "special relationship"] has acquired a life of its own. Instead of being a shorthand for the kind of circumstances ... in which the state either deliberately inflicted injury or greatly increased risk while constricting access to selfhelp-it has become a magic phrase-a category in which to dump cases .... Instead of trying to define the phrase with greater precision, it is better to jettison the language while adhering to the principles that the phrase once summarized. When the state puts a person in danger, the Due Process Clause requires the state to protect him to the extent of ameliorating the incremental risk. When a state cuts off sources of private aid, it must provide replacement protection. ${ }^{162}$

Thus, the idea of foregoing the categorical "special relationship" doctrine in favor of a more direct inquiry into vulnerability and access to assistance is well-supported in literature and case law. The approach this Comment suggests would focus the courts' attention more directly on the important principles implicated by the affirmative duty question:

Certainly the approach suggested in this Comment does not provide easy answers. By asking how vulnerable the victim is in the state-created situation and how much access she had to outside assistance, courts enter into a difficult realm of quantification. How much vulnerability is enough to trigger a duty? Exactly how much must the victim be hindered in her ability to seek help from outside the situation? These difficult and very basic questions have no simple answer. It should be noted, however, that by having the courts wrestle with these questions, instead of trying to make analogies to prisons or to "custody," the courts' attention will be focused more clearly on the underlying concern of when the state should have an affirmative obligation to protect its citizens.

\section{A MidDle Ground ON THE IsSUe OF AFFIRMATIVE DUTY IN THE PUBLIC SchoOLS}

As discussed in Part II, courts have dealt with affirmative duty claims in the public school context in two ways. Either the school officials have a "special relationship" with students (and thus an

161847 F.2d 1211 (7th Cir. 1988) (en banc), cert. denied, 489 U.S. 1065 (1989).

${ }^{162} I d$. at 1123 (emphasis added). 
affirmative duty to protect them), or there is no "special relationship" and the officials cannot be held liable for their inaction. This "all or nothing" approach is not necessary. A court reluctant to expand the scope of affirmative duties could hold that in some public school cases the school defendants do have a duty, without necessarily deciding that such a duty will be imposed in all public school cases. A workable and valid middle ground, rooted in the vulnerability principle discussed in Part III, is conceivable.

The public school affirmative duty cases can be divided into two categories: (1) where the public school officials failed to protect a student from harm inflicted by another student and (2) where the injury was caused by a teacher or public school employee. This Comment argues that courts should find a duty at least where the abuse or molestation is perpetrated by a teacher or school employee. This decision would not be "all or nothing," however. Holding that school officials and districts have an affirmative duty to protect students from abuse or molestation by teachers or school employees, based on the rationale suggested in this Comment, does not dictate an outcome on the question of affirmative duty in the case of abuse of a student by a student. ${ }^{163}$

163 After this Comment was written (but before it was published), a district court in Pennsylvania adopted the distinction that this Comment suggests. A set of companion cases, C.M. v. Southeast Delco Sch. Dist., 828 F. Supp 1179 (E.D. Pa. 1993), and K.L. v. Southeast Delco Sch. Dist., 828 F. Supp. 1192 (E.D. Pa. 1993) dealt with nearly identical accusations of offensive and abusive conduct by a seventh and eighth grade special education teacher. The plaintiff in each case was different, however, and therefore the court issued two separate opinions.

After the D.R. and Black opinions it seemed clear that there was no affirmative duty in the public schools in the Third Circuit. The court in C.M. and K.L., however, found otherwise. Specifically, the court stated that:

[We] find that the question of whether the alleged perpetrator is a state actor is equally determinative.

[We] believe that states $d o$ have an affirmative duty to protect students in public schools from abusive conduct by their teachers. Public school teachers are state employees who are hired by, answerable to, and controllable by, school administrators, who are also state actors. School districts must hire teachers. . . . School districts may fire teachers for "immorality, incompetency, intemperance, cruelty, persistent negligence, mental derangement, .... Teachers are to be rated for competency by the superintendent .... Thus, the school district-a state entity, and its administrators-state employees, are responsible for hiring, firing, monitoring, and evaluating teachers, who are also state employees.

A school district's affirmative duty to protect its students from their teachers derives from these responsibilities, none of which were present in D.R. or Black, since school districts have no such obligations to supervise students .... 
The Fifth Gircuit's decision in Doe v. Taylor hinted at this distinction:

[W] conclude that public school officials have a duty to police the misconduct of their subordinates and to protect schoolchildren from hazards of which the school officials know or should know. Their deliberate indifference to these duties can form the basis of liability against them. This does not mean that school officials are liable in the ordinary course for injuries to students inflicted by fellow students. ${ }^{164}$

While the court did not elaborate on this point, it appears that it did recognize some substantive difference between the two types of cases.

The obvious question, however, is the following: What substantive difference does it make, in terms of Section 1983 liability, whether a student is abused by a teacher or by a fellow student?

The proposal is best understood by rephrasing the relevant inquiry. Instead of asking when a "special relationship" exists, the inquiry should be: For what types of harms to a citizen should a state be held liable if the state is deliberately indifferent? ${ }^{165}$ The

C.M., 828 F. Supp. at 1189 (footnotes omitted) (emphasis added).

While the distinction the court made in this case is the same distinction suggested by this Comment, the rationale the court offered for the distinction is different. In fact, it may be argued that the court's explanation for distinguishing between students harmed by teachers and those harmed by their peers comes dangerously close to adopting a respondeat superior theory of liability. The court seems to argue that because the teacher is employed by the school district or school officials, those officials should be held liable for the abusive behavior of a teacher. It is well-settled, though, that respondeat superior is inapplicable in Section 1983 cases. See Monell v. Department of Social Servs., 436 U.S. 658, 691 (1978).

The court does hint at another rationale for distinguishing between cases of abuse by students and cases of abuse by school personnel. The court speaks of the "great sensitivity of a teacher's job" as an additional reason for making the distinction. $K . L ., 828 \mathrm{~F}$. Supp. at 1195 . While the court never elaborates on the significance of this "sensitivity," the language does seem to recognize the importance of the teacher's position in the classroom. Thus, the court implies that it would be hospitable to the rationale that this Comment offers for distinguishing between student on student abuse versus teacher on student abuse-namely, that the state, by its affirmative action, renders the student particularly vulnerable to harm from teachers and school personnel. These authority figures present unique difficulties not encountered when students are faced with abuse by other students. See infra text accompanying note 166; infra notes $186-88$ and accompanying text.

164 Doe v. Taylor Indep. Sch. Dist., 975 F.2d 137, 147 (5th Cir. 1992) (emphasis added), cert. denied, 113 S. Ct. 1066 (1993).

165 For a discussion of the shortcomings of analyzing the affirmative duty question by asking when a "special relationship" exists, see supra text accompanying notes 16162. 
underlying principles discussed in Part III provide the answer to that question: Harms that occur when the state has placed the citizen in a situation in which she is particularly vulnerable to that type of harm (or at least more vulnerable to it than she would have been if the state had not forced her into the situation), and, particularly, where the state has put the citizen in a situation in which it is difficult for her to seek outside assistance.

This Comment argues that the identity of the perpetrator is relevant to this inquiry. Students are particularly vulnerable to harm inflicted by those in positions of authority, and face unique difficulties in seeking assistance when they are being abused by this type of perpetrator. The state, by creating these positions of authority ${ }^{166}$ and mandating attendance at school, is directly implicated in the child's vulnerability to harm at the hands of teachers or school employees. Hence, when a teacher or school employee is the abuser, the school officials and school districts should be held to an affirmative duty to protect students.

The major underlying assumption beneath this suggested middle ground is that children are particularly vulnerable to harm from school personnel/authority figures and that they face unique difficulties in seeking outside assistance when they are injured by school employees. This assumption is supported by both social science research and case law.

Despite the growing body of literature on the sexual abuse of children, there is surprisingly little research on abuse in school settings specifically. ${ }^{167}$ At least one commentator has suggested that "the presence of sexual abuse in the school context ... [is] a salient problem for researchers, educators, and policymakers" and noted the need for future social science investigation. ${ }^{168}$ Further research is likely to appear shortly, as the number of reported cases of abuse and molestation has increased tremendously over a short period. ${ }^{169}$

166 See infra note 186.

167 See Gail P. Sorenson, Sexual Abuse in Schools: Reported Court Cases from 19871990, 27 EDUC. ADMIN. Q. 460, 462-63 (1991) (explaining, for example, that "the number or percentage of children who are abused in schools is not known").

${ }^{168}$ See id. at 461.

169 "As recently as the early 1980 s, reported judicial decisions dealing with sexual abuse committed by teachers or other school employees against students were exceedingly rare." Sorenson, supra note 167, at 460 . Between 1987 and 1991, however, there were 51 opinions published dealing with such situations. See id. at 463. Some of these cases have received a great deal of publicity. For example, an incident in a Philadelphia-area school involving a music teacher who used fraudulent 
The research that has been done on abuse and molestation in public schools does support the proposition that children are especially vulnerable to abuse by teachers. Dr. Samuel M. Basta and Dr. Robert F. Peterson conducted a study which compared a group of children recently molested by a teacher to a group of children recently molested by a family member. ${ }^{170}$ They evaluated both groups by using the Personality Inventory for Children, a scientific method of measuring mental health in such areas as depression, withdrawal, and anxiety. ${ }^{171}$ They concluded that there were "no significant differences between the two groups. ${ }^{\text {172 }}$ In explaining why abuse by a teacher had as devastating an effect on children as abuse by a primary caregiver, they emphasized the importance of the teacher-child relationship. In many cases, they noted, "[the teacher] spent more time with ... the children than [the children] spent with their own parents." 178

They also made the following observations about the vulnerability of children to abuse by a teacher:

[The teacher] had considerable power over the children's behavior .... He ... use[d] attention, affection, physical contact, and access to privileges to influence them. If a child refused his requests, he or she was not overtly pressured to be involved [in sexual behavior], but did miss out on special activities that were limited to those children who participated....

In many ways, the relationship between [the teacher] and the children was like that of a family member, and in some cases probably closer. . . . Indeed, it may be that those adults with [such] a close nurturing relationship with the child have the potential to create the greatest damage via sexual abuse. ${ }^{174}$

A 1990 article entitled Abuse and Neglect in Schools ${ }^{175}$ noted the unique difficulties encountered by children when faced with the possibility of reporting abuse or molestation by a teacher:

methods to induce a student to perform oral sex on him was the subject of numerous headlines in recent months. See Amy S. Rosenberg, After Arrest, Hurt Settles in at School, PHILA. INQUIRER, Jan. 15, 1993, at B1.

${ }_{170}$ See Samuel M. Basta \& Robert F. Peterson, Perpetrator Status and the Personality

Characteristics of Molested Children, 14 CHILd ABuSE \& Neglect 555, 555 (1990).

171 See id. at 559.

172 Id.

173 Id. at 561.

${ }^{174} \mathrm{Id}$. at 561-63.

175 Max Sugar, Abuse and Neglect in Schools, 44 AM. J. PSYCHOTHERAPY 484 (1990). 
Parents are usually held in high esteem by their offspring and when they abuse their child the youngster denies, splits, and projects the blame and negative affects onto the self or others, but not the idealized parent. . . . It would appear that . . . youngsters do the same about the abusing teacher. Their idealized transference to teachers makes it difficult for them to report the physical/ sexual/emotional abuse . . . that occurs in school. . . . This would explain the relative paucity of reporting of teachers for incidents of child maltreatment . ... 176

There have been a number of well publicized incidents of sexual abuse in day care. While these children are younger than public school students, and day care is different in other respects from a public school, ${ }^{177}$ some of the research done on these cases is helpful. A book entitled Nursery Crimes $^{178}$ documents the infamous McMartin episode in which scores of children were abused in their nursery school over a number of years. In analyzing this pedophilic behavior, the authors rejected the idea that abuse in day care grows out of a specific sexual attraction for these young children. They determined instead that "much of the abuse seems more opportunistic in nature. By opportunistic, we mean ... that the key factor about the children was ... their availability and their vulnerability. $" 179$

Another body of research has focused on the unique problems children face when abused by what individual researchers have dubbed "authority figures." In the first national survey of adults concerning a history of childhood sexual abuse, victimization was reported by $27 \%$ of women, and $16 \%$ of men. ${ }^{180}$ "Half the offenders were seen by the victims to be authority figures." 181

${ }^{176} I d$. at 494 (footnote omitted).

177 Day care program attendance, for one thing, is not mandated by law. In Tilson v. School Dist., No. CIV. A. 89-1923, 1990 WL 98932 (E.D. Pa. July 13, 1990), order affd, 932 F.2d 961 (3d Cir. 1991), for example, the Section 1983 suit of a four-yearold day care student was dismissed because "[p]reschool attendance is not compulsory." Id. at $* 9$.

178 David Finkelhor et al., NuRSery CrImes: Sexual Abuse In Day Care (1988).

${ }^{179} I d$. at 55.

${ }^{180}$ See David Finkelhor et al., Sexual Abuse in a National Survey of Adult Men and Women: Prevalence, Characteristics, and Risk Factors, 14 CHILD ABUSE \& NEGLECT 19, 19 (1990).

${ }^{181} I d$. at 21. 
It should also be noted that studies have revealed that the psychological impact of abuse by authority figures is worse than the impact of abuse by others. A study by Leslie Feinauer found that:

As Browne and Finkelhor (1986) indicated, clinical and popular belief assume that sexual violation by a relative is more traumatic than when someone from outside the family is the perpetrator. Contrary to this notion, the results of this study indicate that family relationship is not as important in determining the trauma of sexual abuse as the type of personal relationship the victim had with the abuser.

The most important finding from this study was the increase in emotional distress seen in victims who were abused by a person who was known to and trusted by them. ${ }^{182}$

While not overtly relying on the type of social science research discussed above, courts have explicitly recognized that certain relationships place the child in a particularly difficult situation when it comes to child abuse. "[U]ncertainty becomes confusion when an abuser who fulfills a caring-parenting role in the child's life tells the child that what seems wrong to the child is, in fact, all right. Because of the child's confusion, shame, guilt, and fear, disclosure of the abuse is often long delayed."183 Indeed, the Supreme Court noted in Pennsylvania v. Ritchie ${ }^{184}$ that "[a] child's feelings of vulnerability and guilt and his or her unwillingness to come forward are particularly acute when the abuser is a parent." 185 Thus, the nation's highest court has recognized that the nature of the relationship between the child and her abuser is relevant to both the vulnerability of the child to injury, and the ability of the child to seek assistance.

Given the in loco parentis ${ }^{186}$ role of the teacher, and the fact

182 Leslie L. Feinauer, Comparison of Long-Term Effects of Child Abuse by Type of Abuse and by Relationship of the Offender to the Victim, 17 AM. J. FAM. THERAPY 48, 54 (1989); see also SANDY K. WURTELE \& CINDY L. MIILER-PERRIN, PREVENTING CHILD SEXUAL ABUSE 14 (1992) (noting that when "children are sexually victimized by people they know and trust[, they] have to deal not only with the trauma of the molestation but also the violation of trust").

${ }^{183}$ State v. Myers, 359 N.W.2d 604, 610 (Minn. 1984).

184480 U.S. 39 (1987).

${ }^{185} \mathrm{Id}$. at 60 (emphasis added).

186 The term in loco parentis refers to a teacher's authority to perform the role of the parent while students are at school. This power is a basic common-law principle. See In re Donaldson, 75 Cal. Rptr. 220, 222 (Dist. Ct. App. 1969); Indiana State Personnel Bd. v. Jackson, 192 N.E.2d. 740, 743-44 (Ind. 1963); see also JOACHIM F. WELTZIN, THE LAW OF AMERICAN PUBLIC EDUCATION 141 (1967) ("In the common 
that literature on child abuse includes "educators," as well as parents, in the category of "authority figures, ${ }^{, 187}$ it follows that courts would accept the idea that the unique difficulties encountered by children when faced with abusive parents also apply when they are faced with abusive teachers.

Abuse by teachers/authority figures thus presents unique problems not faced when students are abused by their peers. Students are uniquely vulnerable to abuse by authority figures because these are people they are supposed to respect and obey and they also have a more difficult time reporting abuse by authority figures than they do reporting abuse by peers. ${ }^{188}$ While students are certainly vulnerable to abuse by their peers, and may also have difficulty reporting such abuse, the unique difficulties faced by students abused by teachers or school personnel-by virtue of their

law, the teacher is said to stand . . . in the place of the parent."). Some states confer this authority statutorily. See FLA. STAT. ANN. \$ 232.256(1) (West 1989); ILL. ANN. STAT. ch. 105, para. 5/34-84a (Smith-Hurd 1993 \& Supp. 1993). The in loco parentis power of teachers is not a wholesale conferral of parental power, however. The Fourth Amendment's prohibition on unreasonable searches and seizures, for example, does apply to searches carried out by school officials. See New Jersey v. T.L.O., 469 U.S. 325, 333 (1985). The Constitution would not, of course, place any restriction on parents.

187 See, e.g., Christopher Bagley \& Kathleen King, Child SeXual ABuSe 74 (1990) (including teachers and ministers as authority figures).

188 Certainly it can be argued that the vulnerability of a student decreases as they become older. A third grader and a senior in high school do not seem equally vulnerable. However, as the Tenth Circuit noted in Maldonado v.Josey, 975 F.2d 727 (10th Cir. 1992), cert. denied, 113 S. Ct. 1226 (1993): "[Y]ounger children are incapable of providing for their own basic needs; they depend on parents or other caretakers to provide for them. Even older children may be forced by school disciplinary procedures and rules to rely on authority figures at school to protect them from harm." Id. at 735 (emphasis added). While the distinction argued for in this Comment may be instinctively more appealing when it involves abuse of young children by their own school teacher, this Comment maintains that even older children are faced with a unique set of difficulties when abused by an authority figure, that they do not have to encounter with when abused by a peer. The distinction should, therefore, not depend on the age of the student.

It is also arguable that "authority figures" is too broad a category if it includes any school employee-for example, janitors and bus drivers. Again, the distinction seems more appealing when cast as abuse by students compared to abuse by teachers. However, the psychological research groups all adults in positions of authority together for those purposes. As a point of fact, one of the most egregious cases of abuse or molestation involved a bus driver. See Black v. Indiana Area Sch. Dist., 985 F.2d 707, 708 (3d Cir. 1993) (" $[\mathrm{P}]$ laintiff schoolchildren allege that they were sexually molested by their school bus driver while being driven in the bus to and from school."). 
authoritative position-would not apply when students are abused by other students.

\section{CONCLUSION}

This Comment suggests that courts should find an affirmative duty in the public school setting at least in cases of abuse or molestation by a teacher or school employee. In this group of cases, the state has coerced the child/citizen into a situation where she is particularly vulnerable to abuse by an authority figure, and faces unique difficulties reporting such abuse. Therefore, applying an affirmative duty would be consistent with the underlying principle of affirmative duty doctrine, as discussed in Part III.

A court which finds a duty in cases where a teacher or school employee is the perpetrator of the abuse is not necessarily obligated to find that such a duty exists when a student is abused by a fellow student. The "all or nothing" approach is not necessary. All of the public school abuse cases are not the same. As noted, there is a significant difference, with regard to vulnerability and ability to seek assistance, between cases in which the perpetrator is a teacher or school employee and cases in which the perpetrator is a student.

The middle ground delineated in this Comment provides an opportunity for a court to leave the door to recovery at least partially open, where it otherwise might have slammed it shut. Given the destructive impact-physically and emotionally-of the injuries suffered by these children, any proposal for preserving the opportunity for a successful claim is essential. 


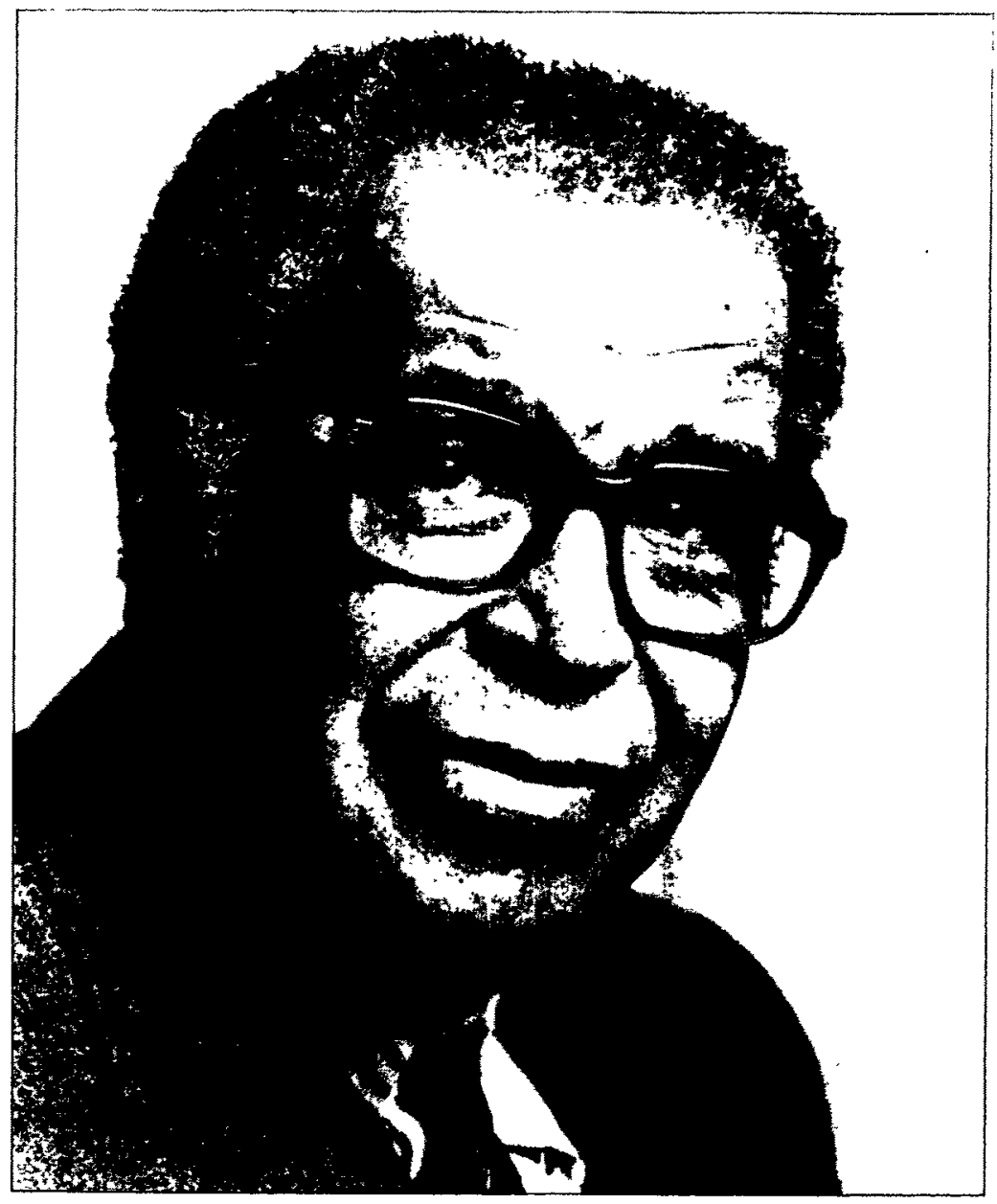

A. LEON HIGGINBOTHAM, JR.

The editors of the University of Pennsyvania Law Review take great pleasure in dedicating this issue to the Honorable A. Leon Higginbotham, Jr., as he leaves his position as Senior Fellow at the University of Pennsylvania Law School. The remarks of this prominent group of contributors honoring Judge Higginbotham illustrate the profound impact he has had on American jurisprudence, legal scholarship, and the nation as a whole. In publishing this Dedication, the Law Review salutes Judge Higginbotham as a jurist, teacher, scholar, and humanitarian. We wish him well in all his future endeavors. 